\title{
Animal and Vegetarian Protein Sources in Relationship with the Risk of Biliary Stone; A Case- Control Study from Iranian Adults
}

\section{Saeedeh Saadati}

NNFTRI

Azita Hekmatdoost ( $\square$ a_hekmat2000@yahoo.com )

NNFTRI https://orcid.org/0000-0002-1944-0052

Hamid Asadzadeh-aghdaei

SBMU

\section{Amir Sadeghi}

SBMU

\section{Seyyed Reza Sobhani}

NNFTRI

\section{Mohammad Amin Shahrbaf \\ SBMU}

Komeil Esmailinejad

SBMU

Alireza Bahrami

NNFTRI

Fatemeh Rahimi-Sakak

NNFTRI

Mohammad Reza Zali

SBMU

\section{Research note}

Keywords: Gallstones, Diet, Plant Proteins, Animal Protein

Posted Date: January 22nd, 2020

DOl: https://doi.org/10.21203/rs.2.21589/v1

License: (c) (i) This work is licensed under a Creative Commons Attribution 4.0 International License.

Read Full License 


\section{Abstract}

\section{Objectives}

Previous studies suggested that protein has a protective effect on the formation of biliary stones. The aim of the current study is the comparison between the effect of animal protein and plant protein on the formation of biliary stone. One hundred and ten cases who had the history of biliary stone disease and 230 controls who were normal in terms of biliary diseases enrolled in this study. Food frequency questionnaire was used for the nutritional assessment; moreover, demographic and anthropometric data, in addition to habitual history and comorbidities were collected by a questionnaire.

Results

Plant protein consumption was significantly lower in cases compared to controls $(p=0.03)$. Furthermore, the relationship between biliary stone disease and animal protein intake was significant in crude model for men (OR: $1.03,95 \% \mathrm{Cl}=1.01-1.05)$ and both sex together (OR: 1.01, 95\% $\mathrm{Cl}=1.00-1.01)$. In addition, the risk of biliary stone was significantly lower in patients with higher consumption of plant protein (for women: OR: $0.94,95 \% \mathrm{Cl}=0.89-0.99$, for both sex: OR: $0.96,95 \% \mathrm{Cl}=0.93-0.99)$. Plant proteins have a significant negative effect on the formation of biliary stone disease compared to animal proteins.

\section{Introduction}

Biliary stones are one of the most common disorders of the biliary system in the world with a $15-20 \%$ prevalence rate in western countries ${ }^{1-4}$. It is also one of the most common diseases affecting emergency-room patients with epigastric pain, nausea, vomiting, abdominal pain, and loss of appetite 5 . The pathogenesis of biliary stones is believed to be multifactorial and probably develops from interactions between several genetic and environmental factors such as age, gender, ethnicity, family history, obesity rapid weight loss and, pregnancy ${ }^{6-8}$.

One of the modifiable risk factors for biliary stones is nutritional intake ${ }^{9-11}$.Dietary proteins have an influence on biliary cholesterol density and biliary stone formation ${ }^{12-14}$. Some of the studies suggest that plant protein intake is associated with lower risk of biliary stones in comparison to animal protein intake ${ }^{1516}$. In addition, some of studies have observed no significant association between protein intake and biliary stones ${ }^{17} 18$.

Assessing the dietary habit in biliary stones patient can determine the relationship between protein intake and biliary stones ${ }^{19}$. The purpose of the current study was to determine the association between plant and animal protein intake with the risk of biliary stone.

\section{Methods}




\section{Study Design}

This case-control study was conductedin Research Institute for Gastroenterology and Liver Diseases of Taleghani hospital (Tehran, Iran) from November 2017 to October 2018. Our samples consisted of 110 cases (aged 21-91 years) who had the history of gallstone or common bile duct (CBD) stone which was confirmed by ultrasonography in a 6 months' period before the presentation to gastrointestinal disease clinic. Furthermore, the control group consist of 230 subjects (aged 23-84 years) who admitted to the other wards of the hospital and did not have the history of biliary stones. Moreover, controls were matched to cases based on age ( \pm 5 years) and sex.

\section{Nutritional Assessment}

In order to assess the dietary consumption of samples during 1 year before biliary stone determination in the case group or hospital admission in the control group, a validated food frequency questionnaire (FFQ) was used ${ }^{20}$. Researchers asked participantsto explain the frequency of their dietary consumption on a daily, weekly, monthly or yearly manner. After that, dietaryintakeswereconverted to daily frequency for each group of protein consumption.

\section{Data Collection}

Demographic data, anthropometric measurements, physical activity, history of smoking, history of alcohol consumption and comorbidities were collected by a questionnaire. Physical activity was assessed by using a validated questionnaire as metabolic equivalents hour/day (METs h/d) ${ }^{21}$. Furthermore, weight measurement was done in standing position by digital scales (Soehnle®, Berlin, Germany) with an accuracy of $100 \mathrm{~g}$. In addition, height was measured using a tape-meter which fixed to a wall with an accuracy of $0.5 \mathrm{~cm}$. BMI was calculated by dividing the weight by the square of height in meter.

\section{Statistical Analysis}

Statistical analysis was conducted on the data by using SPSS software version 16 (SPSS Inc., Chicago, Illinois). Baseline characteristics, biochemical parameters and dietary intakes of study participants between case and control group were compared t-test or Mann-Whitney for quantitative variables and Chisquare test for qualitative variables. Logistic regression was used to calculate the odds ratio of biliary stone disease as the dependent variable in relation to the animal and plant protein as independent variables in 4 models: Crudemodel, model2(adjusted for energy intake and physical activity), model 3 (further controlled for body mass index and history of diabetes) and, model4(additionally adjusted for dietary cholesterol and dietary fiber). The odds ratios of the outcomes were determined with $95 \%$ confidence interval.

\section{Ethical Consideration}

The protocol of study was approved by Research Institute of Gastroenterology and Liver Diseases Ethics Committee (IR.SBMU.RIGLD.REC.1396.159). 


\section{Results}

Baseline characteristics, biochemical parameters and dietary intakes of study participants were shown based on case and control group (Table 1). Individuals in the case group as compared to those in the control group were higher in total energy intake and prevalence of type-2 diabetes and lower in physical activity, protein intake, dietary cholesterol, and dietary fiber ( $p$-value $<0.05)$.

Table 1

Baseline characteristics, biochemical parameters and dietary intakes of study participants based on the patients with biliary stone disease and control group

\begin{tabular}{|c|c|c|c|}
\hline & Cases $(n=110)$ & Controls $(n=230)$ & P valuea \\
\hline Age $(y r)$, mean \pm SD & $57.66 \pm 16.39$ & $56.00 \pm 10.64$ & 0.072 \\
\hline Male n (\%) & $53(48.2)$ & $129(56.1)$ & 0.172 \\
\hline $\mathrm{BMI}(\mathrm{kg} / \mathrm{m} 2)$, mean $\pm \mathrm{SD}$ & $27.04 \pm 5.46$ & $26.70 \pm 4.01$ & 0.884 \\
\hline Physical activity (MET), mean \pm SD & $29.47 \pm 3.33$ & $40.00 \pm 9.35$ & $<0.001$ \\
\hline Current smokers, n (\%) & $29(26.4)$ & $41(17.8)$ & 0.069 \\
\hline Drank alcohol in past year, $\mathrm{n}(\%)$ & $6(5.2)$ & $5(2.2)$ & 0.190 \\
\hline Diabetes type $2, \mathrm{n}(\%)$ & $18(16.4)$ & $20(8.7)$ & 0.036 \\
\hline Total energy (kcal), mean \pm SEM & $2448.28 \pm 61.48$ & $2302.27 \pm 38.11$ & 0.034 \\
\hline Carbohydrate (\% of total energy) , mean \pm SEM & $48.27 \pm 0.80$ & $49.00 \pm 0.44$ & 0.079 \\
\hline Protein (\% of total energy), mean \pm SEM & $12.59 \pm 0.25$ & $13.19 \pm 0.14$ & 0.004 \\
\hline Fat (\% of total energy), mean \pm SEM & $41.53 \pm 0.86$ & $40.91 \pm 0.46$ & 0.682 \\
\hline Dietary cholesterol $(\mathrm{mg} / \mathrm{d})$, mean \pm SEM & $203.30 \pm 8.50$ & $236.99 \pm 6.58$ & 0.001 \\
\hline Saturated fat $(g / d)$, mean \pm SEM & $25.49 \pm 0.85$ & $24.42 \pm 0.38$ & 0.142 \\
\hline Monounsaturated fat $(\mathrm{g} / \mathrm{d})(\mathrm{mg} / \mathrm{d})$, mean \pm SEM & $29.22 \pm 1.21$ & $29.74 \pm 0.56$ & 0.376 \\
\hline Polyunsaturated fat $(\mathrm{g} / \mathrm{d})(\mathrm{mg} / \mathrm{d})$, mean \pm SEM & $21.95 \pm 0.93$ & $22.79 \pm 0.44$ & 0.201 \\
\hline Dietary fiber $(\mathrm{g} / \mathrm{d})$, mean \pm SEM & $36.08 \pm 2.01$ & $40.33 \pm 0.74$ & 0.001 \\
\hline
\end{tabular}

Dietary intake of animal and plant protein base on case and control group for men, women and both sex were shown in Table 2. Men in the case group as compared to men in control group consumed higher animal protein and lower plant protein $(p$-value $<0.05)$. for women there was no significant differences 
between case and control groups. When both sex considered, case group as compared to control group consumed lower plant protein ( $p$-value $<0.05$ ).

Table 2

Animal and plant protein dietary intakes of study participants based on the patients with biliary stone disease and control group

\begin{tabular}{|c|c|c|c|c|c|c|c|c|c|}
\hline & \multicolumn{2}{|l|}{ Men } & \multirow{2}{*}{$\begin{array}{l}P \\
\text { value }\end{array}$} & \multicolumn{2}{|c|}{ Women } & \multirow{2}{*}{$\begin{array}{l}P \\
\text { value }\end{array}$} & \multicolumn{2}{|c|}{ Both sex } & \multirow{2}{*}{$\begin{array}{l}P \\
\text { value }\end{array}$} \\
\hline & $\begin{array}{l}\text { Cases } \\
(\mathrm{n}= \\
53)\end{array}$ & $\begin{array}{l}\text { Controls } \\
(n= \\
129)\end{array}$ & & $\begin{array}{l}\text { Cases } \\
(\mathrm{n}= \\
101)\end{array}$ & $\begin{array}{l}\text { Controls } \\
(n=57)\end{array}$ & & $\begin{array}{l}\text { Cases } \\
(n= \\
110)\end{array}$ & $\begin{array}{l}\text { Controls } \\
(n= \\
230)\end{array}$ & \\
\hline $\begin{array}{l}\text { Animal } \\
\text { protein } \\
\text { intake } \\
\text { (g/day) }\end{array}$ & $\begin{array}{l}52.12 \\
\pm \\
34.84\end{array}$ & $\begin{array}{l}40.37 \pm \\
14.16\end{array}$ & 0.02 & $\begin{array}{l}38.43 \\
\pm \\
19.51\end{array}$ & $\begin{array}{l}39.45 \pm \\
14.79\end{array}$ & 0.32 & $\begin{array}{l}45.03 \\
\pm \\
28.67\end{array}$ & $\begin{array}{l}39.96 \pm \\
14.42\end{array}$ & 0.44 \\
\hline $\begin{array}{l}\text { Plant } \\
\text { protein } \\
\text { intake } \\
\text { (g/day) }\end{array}$ & $\begin{array}{l}28.44 \\
\pm \\
36.19\end{array}$ & $\begin{array}{l}38.56 \pm \\
15.39\end{array}$ & 0.03 & $\begin{array}{l}34.01 \\
\pm \\
21.35\end{array}$ & $\begin{array}{l}32.97 \pm \\
12.38\end{array}$ & 0.54 & $\begin{array}{l}31.33 \\
\pm \\
29.44\end{array}$ & $\begin{array}{l}36.10 \pm \\
14.39\end{array}$ & 0.03 \\
\hline
\end{tabular}

Table 3 shows the odds ratios for the biliary stone disease for male, female and both sex together in four models. In the crude model, there was a significant relationship between biliary stone disease and animal protein intake for male (OR: $1.03,95 \% \mathrm{Cl}=1.01-1.05)$ and both sex together (OR: $1.01,95 \% \mathrm{Cl}=1.00$ -1.01). In fact, patients with higher consumption of animal protein intake were significantly more likely to have the biliary stone disease. In model 2 (adjusted for energy intake and physical activity), model 3 (further controlled for, body mass index and history of diabetes), and model 4 which were adjusted for (additionally adjusted for dietary cholesterol and dietary fiber), these relationships were significant for men, women, and both sex (Table 3). 
Table 3

Odds ratios of biliary stone disease for animal and plant protein intake ${ }^{a}$

\begin{tabular}{|c|c|c|c|c|c|c|}
\hline \multirow[b]{2}{*}{ Animal protein intake } & \multicolumn{2}{|l|}{ Men } & \multicolumn{2}{|c|}{ Women } & \multicolumn{2}{|c|}{ Both sexes } \\
\hline & OR & $95 \% \mathrm{Cl}$ & OR & $95 \% \mathrm{Cl}$ & OR & $95 \% \mathrm{Cl}$ \\
\hline Crude & $1.03^{*}$ & $1.01-1.05$ & 0.99 & $0.98-1.02$ & $1.01 *$ & $1.00-1.02$ \\
\hline Model 2 & $1.04^{*}$ & $1.01-1.08$ & $1.04 *$ & $1.01-1.08$ & $1.03^{*}$ & $1.01-1.06$ \\
\hline Model 3 & $1.04^{\star}$ & $1.00-1.08$ & $1.04 *$ & $1.00-1.08$ & $1.03^{\star}$ & $1.01-1.06$ \\
\hline \multirow[t]{2}{*}{ Model 4} & $1.05^{\star}$ & $1.01-1.10$ & $1.07 *$ & $1.01-1.13$ & $1.05^{\star \star}$ & $1.02-1.08$ \\
\hline & \multicolumn{2}{|l|}{ Men } & \multicolumn{2}{|c|}{ Women } & \multicolumn{2}{|c|}{ Both sexes } \\
\hline Plant protein intake & OR & $95 \% \mathrm{Cl}$ & OR & $95 \% \mathrm{Cl}$ & OR & $95 \% \mathrm{Cl}$ \\
\hline Crude & $0.98 *$ & $0.96-0.99$ & 1.00 & $0.98-1.02$ & 0.99 & $0.98-1.01$ \\
\hline Model 2 & $0.96 *$ & $0.92-0.99$ & $0.94 *$ & $0.89-0.98$ & $0.96 *$ & $0.94-0.99$ \\
\hline Model 3 & 0.96 & $0.92-1.01$ & $0.93 *$ & $0.88-0.98$ & $0.96 *$ & $0.94-0.99$ \\
\hline Model 4 & 0.96 & $0.92-1.01$ & $0.94 *$ & $0.89-0.99$ & $0.96 *$ & $0.93-0.99$ \\
\hline \multicolumn{7}{|c|}{$\begin{array}{l}\text { A: Crude model; B: Model } 2 \text {, multivariate adjusted for energy intake and physical activity; C: Model } 3 \text {, } \\
\text { further controlled for, body mass index and history of diabetes; D: Model } 4 \text {, additionally adjusted } \\
\text { fordietary cholesterol and dietary fiber. Data are presented as the odds ratio }(95 \% \mathrm{Cl}) \text {. ( }{ }^{\star} \text { significant } P \\
\left.\text { value }<0.05 \text {, }{ }^{\star *} \text { significant } P \text { value }<0.01\right)\end{array}$} \\
\hline
\end{tabular}

In the case of the plant protein intake, there was a significant relationship between biliary stone disease and plant protein intake for male in crude model (OR: $0.98,95 \% \mathrm{Cl}=0.96-0.99)$ and model 2 (OR: 0.96, $95 \% \mathrm{Cl}=0.92-0.99$ ). After adjustment for body mass index and history of diabetes in model 3 and dietary cholesterol and dietary fiber in model 4 , this relationship was not significant. For women and both sex, although there was no significant relationship in crude and model 2, there was a significant relationship between biliary stone disease and plant protein intake in model 3 and model 4 . Persons with higher consumption of plant protein intake were significantly less likely to have the biliary stone disease (for women: OR: $0.94,95 \% \mathrm{Cl}=0.89-0.99$, for both sex:OR: $0.96,95 \% \mathrm{Cl}=0.93-0.99$ ) (Table 3).

\section{Discussion}

In this study, nutritional habits, physical activity and protein consumption were investigated on the incidence of biliary stones. Lower rate of physical activity, lower protein intake, fiber intake and dietary cholesterol were associated with higher risk of biliary stone. In addition, energy intake, and the rate of type 2 diabetes were higher in biliary stone patient. 
Many studies have addressed the association of dietary patterns with biliary stones; in the study of Jessri et al, the rate of biliary stone was significantly lower in the patient with healthy nutrition in comparison to unhealthy nutrition ${ }^{9}$. In addition, in the study of Goktas et al, the rate of biliary stone was significantly higher in patients who consumed liquid oil and did not consume milk ${ }^{22}$. Furthermore, Ortega et al suggested that the prevalence of biliary stone is significantly higher in patients with high energy intake, high intake of fat, low fiber intake and low rate of physical activity ${ }^{23}$. Moreover, in the study of Park et al, the rate of cholesterol biliary stone had a direct association with the high intake of lipid, meat and fried food ${ }^{24}$. These results indicate the role of dietary pattern in the formation of biliary stone which is in line with the current study.

In clinical investigations, high plasma level of triglyceride and low plasma level of HDL-C are correlated with higher risk of biliary stones ${ }^{25}$. In addition, proteins have an effective role in biliary stones prevention by increasing the HDL-C and decreasing triglyceride ${ }^{26-28}$. This effect of proteins has been suggested by many animal studies. Ozban et al suggested that the proteins in soya bean decrease the cholesterol level and have a negative effect on biliary stones formation ${ }^{29}$; moreover, Kritchevsky et al demonstrated similar effect of vegetable protein on biliary stone formation ${ }^{28}$. Although the effect of plant protein and animal protein are different in the formation of biliary stones ${ }^{13}$. The possible reason for this difference may be related to the significant effect of the plant protein on the serum concentration of triglyceride ${ }^{30}$. Our study results suggest that the vegetable proteins are associated with lower risk of biliary stone compared to animal proteins. These results are associated with previous studies. Lander et al suggested that plant proteins are significantly related to lower risk of gallstone disease in post-menopausal female ${ }^{11}$; moreover, in the study of Tsai et al the risk of cholecystectomy due to biliary stone was inversely associated with vegetable proteins ${ }^{13}$.

\section{Conclusion}

Dietary habit is associated with biliary stone formation. The proteins have a negative effect on the formation of biliary stones. In addition, vegetable proteins have a significant effect on biliary stone disease compared to animal proteins.

\section{Limitation}

The main limitation of this study was the geographical issue; we evaluate the patients who were in Tehran, the capital of Iran. It will be better to conduct feature study as an epidemiologic evaluation with larger samples.

\section{Abbreviations}

HDL:high-density lipoprotein; CBD:common bile duct; FFQ:food frequency questionnaire; MET:metabolic equivalent task; OR:odds ratio; Cl:confidence interval 


\section{Declarations}

\section{Acknowledgments}

The authors thank the participants of this study, without whom this study was impossible.

Contributors SS, AS, and AH originated the idea for the study and led the protocol design. SS, MZ, AB, and AS conducted the study and supervised the sample and data collection. HA, RS, FRS, KE, and MS were involved in data analysis. SS, AS, and AH were involved in manuscript writing. All authors read and approved the final manuscript.

Funding This study was funded byResearch Institute for Gastroenterology and Liver Diseases, Shahid Beheshti University of Medical Sciences. The funding body did not played any role in the study design, data collection, analysis, and interpretation.

Competing interests None declared.

Patient consent for publication Not required.

Ethics approval Research Institute for Gastroenterology and Liver Diseases, Shahid Beheshti University of Medical Sciences. All participants signed the consent form.

Data availability statement All data relevant to the study are available by corresponding and first authors.

\section{References}

1. Panpimanmas $S$, Manmee C. Risk factors for gallstone disease in a Thai population. Journal of epidemiology 2009;19(3):116-21.

2. Brighi N, Lamberti G, Maggio I, et al. Biliary stone disease in patients receiving somatostatin analogs for neuroendocrine neoplasms. A retrospective observational study. Digestive and liver disease : official journal of the Italian Society of Gastroenterology and the Italian Association for the Study of the Liver 2018.

3. Di Ciaula A, Portincasa P. Recent advances in understanding and managing cholesterol gallstones. F1000Research 2018;7.

4. Seddighi S, Ghidari ME, Sadeghi A, et al. Evaluation of the Cardiovascular Risk in Patients with Biliary Stones; a Descriptive Cross-Sectional Study. Gastroenterology and Hepatology from Bed to Bench 2018.

5. Chen LY, Qiao QH, Zhang SC, et al. Metabolic syndrome and gallstone disease. World journal of gastroenterology 2012;18(31):4215-20.

6. Sun $\mathrm{H}$, Tang H, Jiang S, et al. Gender and metabolic differences of gallstone diseases. World journal of gastroenterology 2009;15(15):1886-91.

7. Marschall HU, Einarsson C. Gallstone disease. Journal of internal medicine 2007;261(6):529-42. 
8. Tarantino G, Magistri P, Ballarin R, et al. Surgery in biliary lithiasis: from the traditional "open" approach to laparoscopy and the "rendezvous" technique. Hepatobiliary \& pancreatic diseases international : HBPD INT 2017;16(6):595-601.

9. Jessri M, Rashidkhani B. Dietary patterns and risk of gallbladder disease: a hospital-based casecontrol study in adult women. Journal of health, population, and nutrition 2015;33(1):39-49.

10. Stinton LM, Shaffer EA. Epidemiology of gallbladder disease: cholelithiasis and cancer. Gut and liver 2012;6(2):172-87.

11. Lander EM, Wertheim BC, Koch SM, et al. Vegetable protein intake is associated with lower gallbladder disease risk: Findings from the Women's Health Initiative prospective cohort. Preventive medicine 2016;88:20-6.

12. Catala I, Juste $C$, Boehler $\mathrm{N}$, et al. Cholesterol crystallization in gall-bladder bile of pigs given cholesterol- $\beta$-cyclodextrin-enriched diets with either casein or soyabean concentrate as protein sources. British Journal of Nutrition 2000;83(4):411-20.

13. Tsai C-J, Leitzmann MF, Willett WC, et al. Dietary protein and the risk of cholecystectomy in a cohort of US women: the Nurses' Health Study. American journal of epidemiology 2004;160(1):11-18.

14. Tseng M, DeVellis RF, Maurer KR, et al. Food intake patterns and gallbladder disease in Mexican Americans. Public health nutrition 2000;3(2):233-43.

15. Tomotake H, Yamamoto N, Yanaka N, et al. High protein buckwheat flour suppresses hypercholesterolemia in rats and gallstone formation in mice by hypercholesterolemic diet and body fat in rats because of its low protein digestibility. Nutrition 2006;22(2):166-73.

16. Mahfouz-Cercone S, Johnson JE, Liepa GU. Effect of dietary animal and vegetable protein on gallstone formation and biliary constituents in the hamster. Lipids 1984;19(1):5-10.

17. Attili AF, Scafato E, Marchioli R, et al. Diet and gallstones in Italy: the cross-sectional MICOL results. Hepatology 1998;27(6):1492-98.

18. Misciagna G, Centonze S, Leoci C, et al. Diet, physical activity, and gallstones-a population-based, case-control study in southern Italy. The American journal of clinical nutrition 1999;69(1):120-26.

19. Hu FB. Dietary pattern analysis: a new direction in nutritional epidemiology. Current opinion in lipidology 2002;13(1):3-9.

20. Asghari G, Rezazadeh A, Hosseini-Esfahani F, et al. Reliability, comparative validity and stability of dietary patterns derived from an FFQ in the Tehran Lipid and Glucose Study. The British journal of nutrition 2012;108(6):1109-17.

21. Heidari Z, Jalali S, Sedaghat F, et al. Dietary patterns and breast cancer risk among Iranian women: A case-control study. European journal of obstetrics, gynecology, and reproductive biology 2018;230:73-78.

22. Goktas SB, Manukyan M, Selimen D. Evaluation of Factors Affecting the Type of Gallstone. Indian Journal of Surgery 2016;78(1):20-26. 
23. Ortega RM, Fernández-Azuela M, Encinas-Sotillos A, et al. Differences in diet and food habits between patients with gallstones and controls. Journal of the American College of Nutrition 1997;16(1):88-95.

24. Park Y, Kim D, Lee JS, et al. Association between diet and gallstones of cholesterol and pigment among patients with cholecystectomy: a case-control study in Korea. Journal of health, population, and nutrition 2017;36(1):39.

25. Méndez-Sánchez N, Zamora-Valdés D, Chávez-Tapia NC, et al. Role of diet in cholesterol gallstone formation. Clinica Chimica Acta 2007;376(1-2):1-8.

26. Parker B, Noakes M, Luscombe N, et al. Effect of a high-protein, high-monounsaturated fat weight loss diet on glycemic control and lipid levels in type 2 diabetes. Diabetes care 2002;25(3):425-30.

27. Zhang J, Wang C, Terroni PL, et al. A high unsaturated fat, high protein and low carbohydrate diet during pregnancy and lactation modulates hepatic lipid metabolism in female adult offspring. American Journal of Physiology-Regulatory, Integrative and Comparative Physiology 2005.

28. Kritchevsky D, Klurfeld DM. Gallstone formation in hamsters: effect of varying animal and vegetable protein levels. The American journal of clinical nutrition 1983;37(5):802-04.

29. Ozben T. Biliary lipid composition and gallstone formation in rabbits fed on soy protein, cholesterol, casein and modified casein. Biochemical journal 1989;263(1):293-96.

30. Anderson JW, Johnstone BM, Cook-Newell ME. Meta-analysis of the effects of soy protein intake on serum lipids. New England Journal of Medicine 1995;333(5):276-82. 